\title{
PENGEMBANGAN PERANGKAT PEMBELAJARAN KOOPERATIF TIPE NHT (NUMBERED HEADS TOGETHER) UNTUK MELATIHKAN KETERAMPILAN BERKOMUNIKASI DAN MENINGKATKAN HASIL BELAJAR PADA MATERI LARUTAN ELEKTROLIT DAN NONELEKTROLIT
}

\author{
Hasnawati $^{1)}$, Rudiana Agustini ${ }^{2)}$, Toeti Koestiari ${ }^{3)}$ \\ ${ }^{1)}$ Mahasiswa Program Studi Pendidikan Sains, Program Pascasarjana Universitas Negeri Surabaya \\ ${ }^{2), 3)}$ Dosen Pascasarjana Prodi Pendidikan Sains Univesrtitas Negeri Surabaya \\ E-mail: hasnawatienna@gmail.com
}

\begin{abstract}
The aims of this study are to develop a cooperative learning type NHT (Numbered Heads Together). The typeis feasible (valid, practical, and effective) and can to practice communication skills, learning outcomes in the material of electrolyte and nonelectrolyte solution in the second semester students of class X State High School 1 Peso. Development of the learning is done based on the models of four-D. This study use done group pretest posttest design. Based on research data obtain findings: the validity of the research developed a good categorized; text book readability level students the developed a good category; good categorized enforceability of RPP; student's dominant activity is to communicate information ideas/ opinions, ask questions, and presentations with the percentage of $18.88 \%$; the obstacles encountered during the implementation of the learning device that students are not familiar with the cooperative model type NHT (Numbered Heads Together) and the majority of students are less active in the learning process; students responded positively to the learning process; teaching and learning process using cooperative learning type NHT (Numbered Heads Together) is able to practice the students communication skills; and student learning outcomes after participating in the learning process is completed $100 \%$. The conclusion of this studyis the cooperative learning type NHT (Numbered Heads Together) feasible (valid, practical, andeffective) used to practice communication skills and learning out comes on the material of electrolyte and nonelectrolyte solution.
\end{abstract}

Keywords: Cooperative Learning Type NHT, Communication Skills, Learning Outcomes

Abstrak: Penelitian ini bertujuan untuk mengembangkan perangkat pembelajaran kooperatif tipe NHT (Numbered Heads Together) yang layak (valid, praktis, dan efektif), melatihkan keterampilan berkomunikasi serta mengetahui hasil belajar pada materi larutan elektrolit dan nonelektrolit pada siswa kelas X semester II SMA Negeri 1 Peso. Pengembangan perangkat pembelajaran dilakukan berdasarkan model four-D. Rancangan penelitian menggunakan One Group Pretest-Posttest Design. Berdasarkan data penelitian diperoleh beberapa temuan:validitas perangkat pembelajaran yang dikembangkan berkategori baik; tingkat keterbacaan Buku Ajar Siswa yang dikembangkan berkategori tepat untuk pembelajaran; keterlaksanaan RPP berkategori baik; aktivitas siswa yang dominan adalah mengkomunikasikan informasi ide/pendapat, bertanya, dan presentasi dengan persentase $18,88 \%$; hambatan yang ditemui selama penerapan perangkat pembelajaran yaitu siswa belum terbiasa dengan model kooperatif tipe NHT (Numbered Heads Together) dan sebagian siswa kurang aktif dalam proses pembelajaran; siswa memberikan respon positif terhadap proses pembelajaran; pembelajarankooperatif tipe NHT(Numbered Heads Together) dapat melatihkan keterampilan berkomunikasi siswa; dan hasil belajar siswa setelah mengikuti proses belajar mengajar adalah tuntas 100\%. Kesimpulan dari penelitian ini adalah perangkat pembelajaran kooperatif tipe NHT (Numbered Heads Together) layak (valid, praktis, dan efektif) digunakan untuk melatihkan keterampilan berkomunikasi dan hasil belajar pada materi larutan elektrolit dan nonelektrolit.

Kata kunci: Pembelajaran Kooperatif Tipe NHT,Keterampilan Berkomunikasi, Hasil Belajar

\section{PENDAHULUAN}

Pendidikan merupakan salah satu faktor penentu kualitas suatu bangsa. Selain karena pendidikan dipandang sebagai sarana untuk melahirkan insan-insan yang cerdas dan kreatif, juga karena pendidikan berperan penting dalam perkembangan peradaban manusia di dalamnya. Bangsa yang mempunyai peradaban maju adalah bangsa dengan sumber daya manusia yang berkualitas. Sumber daya manusia yang berkualitas ini sangat dibutuhkan dalam menghadapi era abad 21 yang menuntut untuk selalu mengikuti pesatnya kemajuan ilmu pengetahuan, informasi, dan teknologi. 
Peningkatan kemampuan dan keterampilan bagi generasi muda calon tenaga kerja juga merupakan tanggung jawab dunia pendidikan. Wagner (2008) menekankan tujuh soft skills yang memiliki nilai penting di era abad 21, yakni: berpikir kritis dan pemecahan masalah; kolaborasi melalui jaringan dan memimpin dengan pengaruh; lincah dan mampu menyesuikan diri; inisiatif dan kewirausahaan; komunikasi yang efektif baik lisan maupun tulisan; mengakses dan menganalisis informasi; dan imajinasi dan daya khayal.

Mengingat pentingnya peranan pendidikan dalam kemajuan bangsa, pemerintah berupaya melakukan perbaikan dan pembaharuan secara bertahap dan terus menerus yang diwujudkan dalam penerapan Kurikulum 2013. Kurikulum 2013 merupakan revisi dan pengembangan dari Kurikulum Tingkat Satuan Pendidikan (KTSP). Tema dari Kurikulum 2013 adalah menghasilkan insan yang: produktif, kreatif, inovatif, afektif; melalui penguatan sikap, keterampilan, dan pengetahuan yang terintegrasi. Untuk mewujudkan hal tersebut, guru dituntut untuk secara profesional merancang pembelajaran efektif dan bermakna, mengorganisasikan pembelajaran, memilih pendekatan pembelajaran yang tepat, menentukan prosedur pembelajaran dan pembentukan kompetensi secara efektif, serta menetapkan kriteria keberhasilan (Mulyasa, 2013).

Berbagai usaha yang telah dilakukan para praktisi pendidikan untuk meningkatkan mutu pendidikan, namun sejauh ini belum menunjukkan hasil seperti yang diharapkan. Rendahnya hasil belajarIPA ditinjau dari tingkat berpikir kritis di Indonesia dapat dilihat dari hasil penelitian Internasional yang dilaksanakan oleh TIMSS (Trends in International Mathematic and Science Study). TIMSS merupakan sistem perbandingan pencapaian siswa dalam bidang matematika dan IPA antar negara yang diselenggarakan secara periodik. Hasil tes TIMSS 2003 yang dikoordinir oleh The International for Evaluation of Education Achievement (IEA) menempatkan siswa Indonesia pada peringkat 36 penguasaan IPA dari 45 negara yang terlibat. Pada tahun 2007, dari 48 negara yang terlibat Indonesia menduduki peringkat 35(Williams, et al., 2009).

Rendahnya kualitas proses maupun hasil belajar juga terjadi pada pembelajaran kimia di SMA Negeri 1 Peso, kabupaten Bulungan, propinsi Kalimantan Utara. Data terbaru yang diperoleh peneliti adalah nilai Ujian Akhir semester 1 kelas $\mathrm{X}$ dimana rata-rata nilai kelas sebesar 65 dengan ketuntasan belajar secara klasikal 70. Salah satu penyebab rendahnya hasil belajar adalah metode yang diterapkan cenderung bersifat menoton sehingga siswa merasa bosan terhadap pembelajaran.

Berdasarkan karakteristik pelajaran kimia dan permendiknas yang lebih menekankan pada pengetahuan produk dan proses maka pembelajaran kimia di SMA diharapkan dapat bermakna dan menyenangkan. Guru diharapkan lebih kreatif dan inovatif dalam mengembangkan bahan ajar dengan menerapkan model pembelajaran yang sesuai dengan karakteristik kimia. Dampaknya adalah hasil belajar dapat meningkat dan pembelajaran lebih menyenangkan.

Materi yang dipilih peneliti adalah larutan elektrolit dan nonelektrolit. Materi ini memiliki beberapa karakteristik sebagai berikut: (1) bersifat abstrak, seperti pada teori ion Svante Arrhenius serta terurainya larutan menjadi ion-ion yang dapat menghantarkan arus listrik, (2) pemahaman konsep, yaitu konsep elektrolit dan nonelektrolit, dan (3) penerapan konsep, yaitu pada saat menguji larutan untuk membedakan larutan elektrolit dan nonelektrolit. Karakteristik materi larutan elektrolit dan nonelektrolit ini menjadi salah satu penyebab kesulitan belajar siswa. Materi ini sangat penting dan berkaitan erat dengan kehidupan sehari-sehari sehingga mudah untuk didiskusikan.

Berdasarkan kenyataan yang ada di lapangan tersebut, maka salah satu alternatif inovasi model pembelajaran yang diharapkan dapat memberikan solusi dan suasana yang menarik, meningkatkan minat belajar siswa, aktivitas siswa,berdiskusi, serta keterampilan berkomunikasi siswa dalam pengajaran adalah model pembelajaran kooperatif. Model pembelajaran kooperatif merupakan model pembelajaran inovatif yang menggunakan kelompok kecil sebagai sarana belajar siswa. Seperti yang dikemukakan Slavin (Isjoni, 2009) "Pembelajaran kooperatif merupakan suatu model pengajaran dimana siswa bekerjasama dalam kelompok kecil yang terdiri dari 4-5 orang dan anggota-anggotanya bersifat heterogen dipandang dari segi etnis, jenis kelamin, dan hasil belajar". Sependapat dengan uraian di atas,Roger, dkk. (Huda, 2011) menyatakan bahwa "Cooperatif learning is group learning activity organized in such a way that learning is based on the socially structured change of information between learners in group in which each learner is held accountable for his or her own learning and motivated to increase the learning of others, yang berarti pembelajaran kooperatif merupakan aktivitas pembelajaran kelompok yang diorganisasi oleh satu prinsip bahwa pembelajaran harus didasarkan pada perubahan informasi secara sosial diantara kelompokkelompok pembelajar yang di dalamnya setiap pembelajaran bertanggung jawab atas pembelajarannya sendiri dan didorong untuk meningkatkan pembelajaran anggota-anggota yang lain.

Keuntungan dari model kooperatif ialah adanya ketergantungan positif, tanggung jawab individual, interaksi personal, dan keahlian bekerjasama. Berdasarkan hasil penelitian Zakaria, et al., (2010) menyatakan pembelajaran kooperatif adalah 
pembelajaran yang efektif, sehingga guru perlu menggunakan dalam proses pembelajaran.

Salah satu tipe pembelajaran kooperatif yang dapat membangun kerjasama antar siswa dan mendorong partisipasi mereka dalam kelas adalah model pembelajaran kooperatif tipe NHT (Numbered Heads Together). Berdasarkan hasil penelitian Rositawati (2012), bahwa model pembelajaran kooperatif tipe NHT (Numbered Heads Together) dapat meningkatkan aktivitas kerja kelompok dan hasil belajar, dapat meningkatkan sikap positif, dapat memotivasi pada waktu kerja kelompok, memberikan kepercayaan diri pada siswa, dan belajar menjadi menyenangkan. Model pembelajaran kooperatif tipe NHT (Numbered Heads Together) pada dasarnya merupakan sebuah varian Diskusi Kelompok; ciri khasnya adalah guru hanya menunjuk seorang siswa yang mewakili kelompoknya, tanpa memberi tahu terlebih dahulu siapa yang akan mewakili kelompok tersebut. Cara ini menjamin keterlibatan total semua siswa dan merupakan upaya yang sangat baik untuk meningkatkan tanggung jawab individual dalam diskusi kelompok (Nur, 2011). Menurut Rabbani (2013) menyatakan bahwa model pembelajaran kooperatif tipe NHT (Numbered Heads Together) merupakan model pembelajaran yang memberikan kesempatan bagi siswa untuk saling berkomunikasi aktif dalam menyelesaikan tugas-tugas mereka, juga melibatkan siswa untuk mengemukakan pendapat sendiri ketika berdiskusi dengan kelompoknya. Diskusi merupakan kegiatan berinteraksi dengan saling bertukar pendapat, sehingga keterampilan berkomunikasi siswa diharapkan dapat berkembang melalui model pembelajaran ini.

Menurut Citrobroto (1982) berdasarkan cara penyampaian dalam komunikasi dibagi menjadi dua yaitu komunikasi lisan dan komunikasi tulisan. Indikator keterampilan komunikasi lisan adalah menjawab pertanyaan, mengajukan pertanyaan, menyampaikan pendapat tentang materi yang dibahas, dan menanggapi pendapat siswa lain saat diskusi kelompok atau diskusi kelas, serta mampu berbicara/ menyampaikan hasil diskusi di depan kelas. Sementara itu indikator keterampilan komunikasi tulisan adalah mendeskripsikan situasi masalah serta menyatakan solusi masalah menggunakan gambar, konsep, dan secara matematis. Menurut Santrock (2007) keterampilan komunikasi adalah keterampilan yang diperlukan guru dalam berbicara, mendengar, mengatasi hambatan komunikasi verbal, memahami komunikasi nonverbal dari murid dan mampu memecahkan konflik secara konstruktif. Sependapat dengan uraian di atas, Eggen, dkk. (2012) menambahkan bahwa keterampilan komunikasi adalah ketika guru menggunakan pengetahuannya dalam teknik komunikasi verbal, nonverbal dan melalui media komunikasi secara efektif untuk mempertahankan keaktifan dalam bertanya, kolaborasidan interaksi siswa yang sifatnya mendukung di dalam kelas.

Keterampilan berkomunikasi yang akan diamati dalam penelitian ini adalah keterampilan berkomunikasi lisan yang meliputi: mengajukan pertanyaan, menjawab pertanyaan, menyumbang ide/pendapat, menanggapi pendapat siswa lain saat diskusi kelompok maupun diskusi kelas, mampu menyampaikan hasil diskusi dan eksperimen di depan kelas. Penelitian terhadap keterampilan berkomunikasi lisan dilakukan karena sebagian besar siswa di sekolah cenderung pasif, tidak berani mengungkapkan pendapatnya, dan menunggu perintah dari guru.

Pembelajaran keterampilan berkomunikasi yang menggunakan model pembelajaran kooperatif tipe NHT (Numbered Heads Together) bertujuan untuk menciptakan suasana pembelajaran yang menyenangkan dan menjadikan siswa berani berpendapat serta menghargai pendapat orang lain. Keterampilan berkomunikasi sangat diperlukan untuk mencapai keberhasilan dalam belajar. Keterampilan berkomunikasi siswa akan mudah mengkomunikasikan berbagai hal yang menyangkut materi pembelajaran, baik secara lisan maupun tulisan.

\section{METODE PENELITIAN}

Penelitian in imerupakan penelitian pengembangan karena mengembangkan perangkat pembelajaran yang meliputi Rencana Pelaksanaan Pembelajaran (RPP), Lembar Kegiatan Siswa (LKS), dan Tes Hasil Belajar (THB) dengan menerapkan model pembelajaran kooperatif tipe NHT (Numbered Heads Together). Penelitian ini dilaksanakan untuk menghasilkan perangkat pembelajaran kimia pada materi larutan elektrolit dan nonelektrolit SMA, yang selanjutnya akan diujicobakan di kelas.

Penelitian ini menggunakan model One Group Pretest-Postest Design yang dikembangkan oleh Campbell and Stanley dalam Arikunto (2010). Desain penelitian ini dapat digambarkan sebagai berikut:

\section{$\mathrm{O}_{1} \mathrm{X} \mathrm{O}_{2}$}

Keterangan:

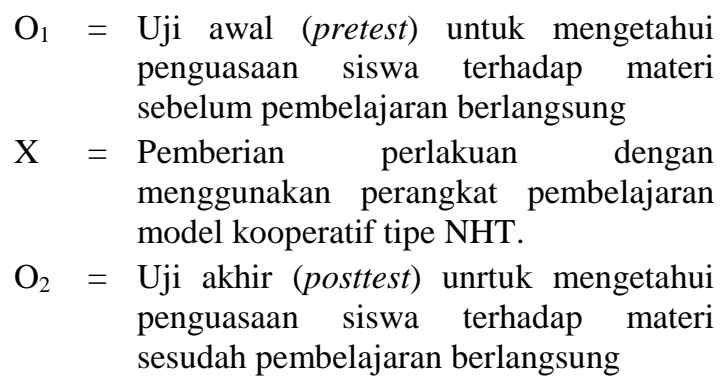

Prosedur penelitian menggunakan rancangan pengembangan perangkat pembelajaran model 4D (four 
$D$ model). Menurut Ibrahim (2002) bahwa untuk merancang perangkat pembelajaran menggunakan four$D$ model terdiri dari empat tahapan yaitu pendefinisian (define), perancangan (design), pengembangan (develop), dan penyebaran (disseminate). Dalam penelitian ini hanya sampai tahap ketiga (pengembangan), sedangkan tahap keempat tidak dilaksanakan mengingat keterbatasan waktu. Data penelitian diperoleh dari siswa kelas X SMAN 1 Peso kabupaten Bulungan. Analisis data dilakukan dengan teknik analisis statistik deskriptif kuantitatif dan kualitatif.

\section{HASIL PENELITIAN DAN DISKUSI}

Berdasarkan hasil analisis data dapat disampaikan beberapa hal sebagai berikut:

\section{A. Kevalidan Perangkat Pembelajaran}

1. Hasil Validasi Perangkat Pembelajaran

Perangkat pembelajaran yang dikembangkan pada penelitian ini adalah Rencana Pelaksanaan Pembelajaran (RPP), Lembar Kegiatan Siswa (LKS), Buku Ajar Siswa (BAS), dan Tes Hasil Belajar Aspek Pengetahuan. Untuk mendapatkan perangkat pembelajaran yang layak digunakan dalam proses pembelajaran, maka dilakukan validasi oleh validator ahli dan uji coba terbatas. Hasil validasi perangkat pembelajaran dapat disimpulkan bahwa: Hasil telaah RPP adalah layak digunakan dan berkategori baik; (2) Hasil telaah BAS adalah layak digunakan dan berkategori baik; (3) Hasil telaah LKS adalah layak digunakan dan berkategori baik; (4) Pada tes hasil belajar aspek pengetahuan, proses validasi dengan hasil dinyatakan valid.

2. Keterbacaan Buku Ajar Siswa

Tingkat keterbacaan BAS menggunakan CloseProcedure. Kriteria persentase tingkat keterbacaan buku ajar siswa adalah sebagai berikut: Di atas $60 \%$ (tingkat bebas) : materi terlalu mudah $40 \%$ $60 \%$ (tingkat pembelajaran) : materi tepat untuk pembelajaran. Di bawah 40\% (tingkat tekanan): materi terlalu sulit, (Taylor, dalam Zuhra 2013)

Tingkat BAS yang dikembangkan diperoleh sebesar 55,4\%, sehingga termasuk dalam kriteria kategori materi tepat untuk pembelajaran.

\section{B. Kepraktisan Perangkat Pembelajaran \\ 1. Keterlaksanaan RPP}

Hasil pengamatan terhadap keterlaksanaan RPP dengan menggunakan model pembelajaran Kooperatif tipe NHT (Numbered Heads Together) yang dilakukan oleh dua orang pengamat menggunakan lembar pengamatan keterlaksanaan RPP (LPK RPP), dihitung reliabilitasnya, dan disajikan secara ringkas pada tebel 1 berikut.
Tabel 1. Reliabilitas LPK RPP

\begin{tabular}{|l|l|l|l|}
\hline \multirow{2}{*}{$\begin{array}{l}\text { Pengamat } \\
\text { an } \\
\text { terhadap }\end{array}$} & \multicolumn{2}{|l|}{$\begin{array}{l}\text { Reliabilitas RPP tiap } \\
\text { pertemuan }(\boldsymbol{\%})\end{array}$} & $\begin{array}{l}\text { Rata- } \\
\text { rata } \\
(\boldsymbol{\%})\end{array}$ \\
\cline { 2 - 3 } & $\mathbf{1}$ & $\mathbf{2}$ & 95.60 \\
\hline Guru & 94.54 & 95.65 & \\
\hline
\end{tabular}

Tabel 1. Menunjukkan bahwa reliabilitas instrumen pembelajaran masing-masing RPP melebihi $75 \%$, dengan rata-rata sebesar $95.60 \%$. Keterlaksanaan RPP juga dinyatakan dengan persentase keterlaksanaan dan kualitas nilai keterlaksanaan disajikan pada tabel 2.

Tabel 2. Penilaian Keterlaksanaan RPP

\begin{tabular}{|l|l|c|l|}
\hline \multirow{2}{*}{$\begin{array}{l}\text { N } \\
\mathbf{N}\end{array}$} & \multirow{2}{*}{$\begin{array}{l}\text { Aspek yang } \\
\text { Dinilai }\end{array}$} & $\begin{array}{l}\text { Keterlaksanaan } \\
\text { RPP }\end{array}$ & \multirow{2}{*}{$\begin{array}{l}\text { Katego } \\
\text { ri }\end{array}$} \\
\cline { 2 - 3 } & $\begin{array}{l}\text { Kegiatan } \\
\text { Pendahulain }\end{array}$ & 3.58 & Baik \\
\hline 2 & Kegiatan Inti & 3.75 & Baik \\
\hline 3 & Penutup & 4.00 & Baik \\
\hline 4 & Suasana kelas & 4.00 & Baik \\
\hline $\begin{array}{l}\text { Rata-rata nilai } \\
\text { keterlaksanaan RPP }\end{array}$ & $\mathbf{3 . 8 3}$ & Baik \\
\hline
\end{tabular}

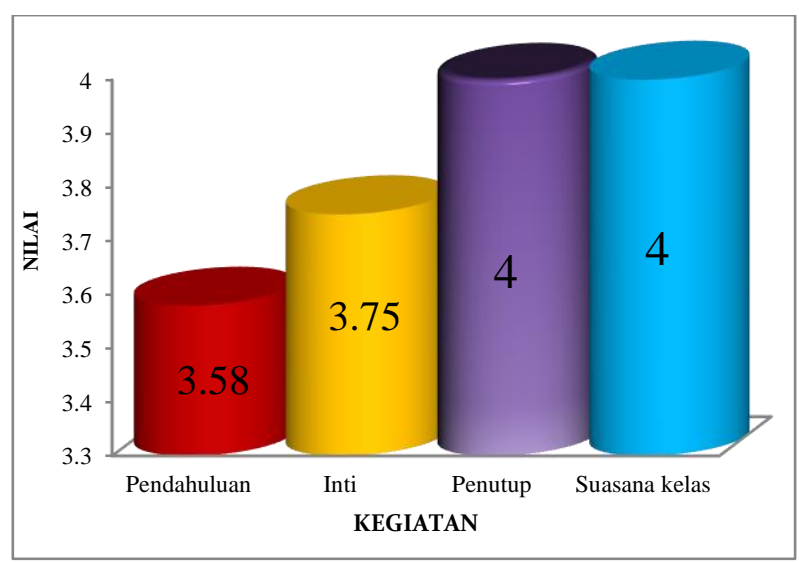

Gambar 1. Nilai Keterlaksanaan RPP

Berdasarkan Tabel 2 dan Gambar 1 tentang keterlaksanaan RPP menunjukkan bahwa kemampuan guru dalam melaksanakan pembelajaran meliputi aspek kegiatan pendahuluan dengan nilai 3,58 kategoribaik, kegiatan inti nilai 3,75 kategori baik, kegiatan penutup 4,00 kategori baik, dan suasana kelas nilai 4,00 kategori baik. Rata-rata nilai keterlaksanaan RPP sebesar 3,33 dengan kategori baik.

Hasil analisis data disajikan dari tabel di atas menunjukkan bahwa guru dapat melaksanakan semua skenario pembelajaran yan direncanakan dalam RPP dengan baik.

\section{Aktivitas Siswa}

Aktivitas siswa selama pembelajaran diamati oleh dua orang pengamat menggunakan lembar pengamatan aktivitas siswa (LPAS).Reliabilitas lembar pengamatan aktivitas siswa (LPAS) disajikan pada Tabel 3. 
Tabel 3. Reliabilitas Lembar Pengamatan Aktivitas Siswa dalam KBM

\begin{tabular}{|c|c|c|c|}
\hline \multirow{2}{*}{$\begin{array}{l}\text { Pengamat } \\
\text { an } \\
\text { terhadap }\end{array}$} & \multicolumn{2}{|c|}{$\begin{array}{l}\text { Reliabilitas Aktivitas } \\
\text { Siswatiap Pertemuan (\%) }\end{array}$} & \multirow{2}{*}{$\begin{array}{l}\text { Rata- } \\
\text { rata } \\
(\%)\end{array}$} \\
\hline & 1 & 2 & \\
\hline Siswa & 92.92 & 95.59 & 94.27 \\
\hline
\end{tabular}

Tabel 3 menunjukkan bahwa rata-rata reliabilitas lembar pengamatan aktivitas siswa yaitu sebesar 94,27\%. Data aktivitas siswa selama KBM disajikan dalam Tabel 4.

Tabel 4. Aktivitas Siswa selama KBM

\begin{tabular}{|c|c|c|}
\hline No. & Aspek Yang Diamati & $\begin{array}{l}\text { Rata- } \\
\text { rata } \\
\text { Aktivitas } \\
\text { siswa } \\
(\%)\end{array}$ \\
\hline 1 & $\begin{array}{l}\text { Membaca buku siswa (mencari } \\
\text { informasi tentang materi ) }\end{array}$ & 10,57 \\
\hline 2 & Mendengarkan penjelasan guru & 12,17 \\
\hline 3 & $\begin{array}{l}\text { Mengerjakan LKS dan } \\
\text { mendiskusikan tugas }\end{array}$ & 13,60 \\
\hline 4 & $\begin{array}{lr}\text { Melakukan } & \text { percobaan, } \\
\text { pengamatan seperti } & \text { petunjuk } \\
\text { pada LKS } & \end{array}$ & 12,17 \\
\hline 5 & Mencatat & 13,60 \\
\hline 6 & Bertanya pada teman dan guru & 17,54 \\
\hline 7 & $\begin{array}{l}\text { Mengkomunikasikan informasi } \\
\text { meliputi menyumbang ide/ } \\
\text { pendapat, } \\
\text { presentasi. }\end{array}$ & 18,88 \\
\hline 8 & Perilaku tidak relevan & 1,52 \\
\hline \multicolumn{2}{|c|}{ Jumlah } & 100 \\
\hline
\end{tabular}

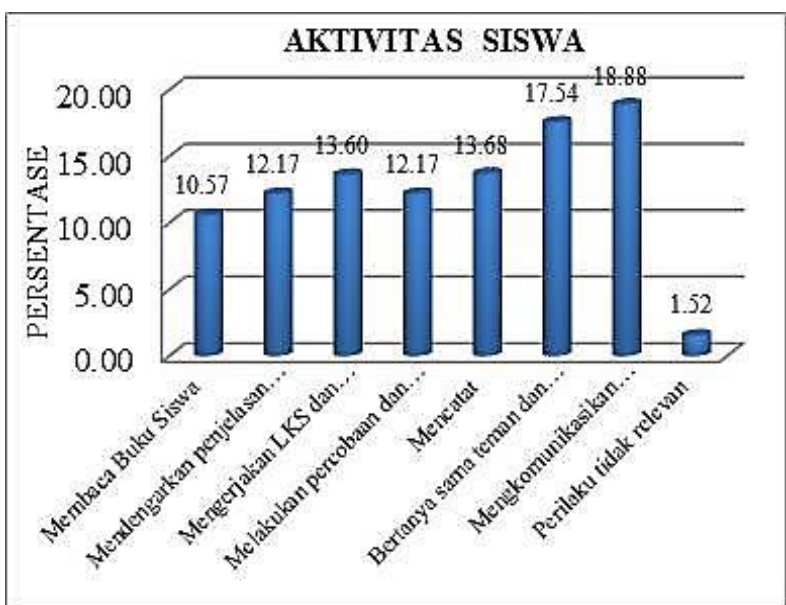

Gambar 2. Persentase Aktivitas Siswa

Berdasarkan diagram batang tentang persentase aktivitas siswa dakam KBM, dapat dikemukakan bahwa persentase aktivitas yang dominan dilakukan siswa adalah mengkomunikasikan informasi meliputi menyumbang ide/pendapat, bertanya dan presentasi yaitu 18,88\%. Dengan demikian aktivitas yang dilakukan siswa tersebut menunjukkan aktivitas yang sudah sesuai dengan pembelajaran kooperatif. Hal ini memberikan kesempatan kepada siswa untuk berlatih berkomunikasi dalam mempresentasikan hasil diskusi atau eksperimennya. Sesuai dengan tujuan Kurikulum 2013 untuk menghasilkan peserta didik sebagai manusia yang mandiri dan tak berhenti belajar, proses pembelajaran dalam RPP dirancang berpusat pada peserta didik untuk mengembangkan motivasi, rasa ingin tahu, kreativitas, kemandirian, keterampilan belajar dan mendorong partisipasi aktif peserta didik (Permendikbud No. 81A).

\section{Hambatan yang Ditemui}

Hambatan yang ditemui selama penerapan perangkat pembelajaran dengan menggunakan model kooperatif tipe NHT (Numbered Heads Together) untuk melatihkan keterampilan berkomunikasi relatif baru dan belum terbiasa bagi siswa. Terutama langkah-langkah pembelajaran kooperatif tipe NHT (Numbered Heads Together). Sehingga untuk mengatasi masalah ini peneliti memerlukan waktu sendiri untuk menjelaskan bagaimana proses belajar menggunakan pembelajaran kooperatif tipe NHT (Numbered Heads Together).

Hambatan lainnya adalah pada pertemuan pertama, tidak semua siswa aktif dalam proses KBM terutama pada saat melakukan percobaan serta mengerjakan LKS, sebagian dari mereka sering mengganggu teman lain. Adapun solusinya yaitu peneliti mengingatkan siswa bahwa pada akhir pembelajaran akan diberikan tes formatif dan memberikan pertanyaan atau menunjuk nomor siswa yang kurang aktif untuk mempresentasikan hasil praktikumnya

\section{Kefektifan Perangkat Pembelajaran}

1. Respon Siswa

Respon siswa terhadap pembelajaran kooperatif tipe NHT pada materi larutan elektrolit dan nonelektrolit dengan menggunakan lembar angket respon siswa (LARS). Angket respon siswa diisi setelah pembelajaran selesai. Data yang diperoleh pada Tabel 5 .

Tabel 5. Respon Siswa Terhadap Pembelajaran Kooperatif Tipe NHT

\begin{tabular}{|c|c|c|c|}
\hline No & Kegiatan yang Direspon & Respon & Persentase \\
\hline \multirow[b]{2}{*}{1} & \multirow[b]{2}{*}{ Kegiatan pembelajaran } & Senang & 93.3 \\
\hline & & $\begin{array}{l}\text { Tidak } \\
\text { Senang }\end{array}$ & 6.7 \\
\hline \multirow[b]{2}{*}{2} & \multirow{2}{*}{$\begin{array}{l}\text { Kebaruan komponen } \\
\text { kegiatan pembelajaran }\end{array}$} & Baru & 94.0 \\
\hline & & $\begin{array}{r}\text { Tidak } \\
\text { Baru }\end{array}$ & 6.0 \\
\hline 3 & mengikuti & $\mathrm{Ya}$ & 100 \\
\hline
\end{tabular}




\begin{tabular}{|l|l|c|c|}
\hline \hline & pembelajaran dengan & Tidak & 0 \\
\hline model yang sama & $\begin{array}{l}\text { Keterampilan kooperatif } \\
\text { dan keterampilan } \\
\text { berkomunikasi }\end{array}$ & $\begin{array}{l}\text { Senang } \\
\text { Tidak } \\
\text { Senang }\end{array}$ & 94.2 \\
\hline \multirow{2}{*}{5} & $\begin{array}{l}\text { Kebaruan keterampilan } \\
\text { kooperatif } \\
\text { keterampilan } \\
\text { berkomunikasi }\end{array}$ & Baru & 88.9 \\
\cline { 3 - 4 } & & $\begin{array}{l}\text { Tidak } \\
\text { Baru }\end{array}$ & 11.1 \\
\hline
\end{tabular}

Berdasarkan analisis data di atas dapat disimpulkaan bahwa siswa memberikan respon positif dan baik terhadap pembelajaran kimia dengan menggunakan model kooperatif tipe NHT (Numbered Heads Together).

\section{Keterampilan Berkomunikasi Siswa}

Selama proses pembelajaran berlangsung di kelas,dilakukan pengamatan terhadap keterampilan berkomunikasi siswa.Berikut disajikan Tabel 6 tentang pengamatan keterampilan berkomunikasi siswa.

Tabel 6. Keterampilan berkomunikasi Siswa selama KBM

\begin{tabular}{|c|l|l|}
\hline No. & $\begin{array}{l}\text { Keterampilan Berkomunikasi } \\
\text { Siswa yang Diamati }\end{array}$ & $\begin{array}{l}\text { Rata- } \\
\text { rata } \\
\mathbf{( \% )}\end{array}$ \\
\hline 1 & Mengajukan pertanyaan & 7,85 \\
\hline 2 & Menjawab pertanyaan & 18,17 \\
\hline 3 & Menyumbang ide/ pendapat & 24,71 \\
\hline 4 & $\begin{array}{l}\text { Menanggapi pendapat siswa lain } \\
\text { saat diskusi kelompok maupun } \\
\text { diskusi kelas }\end{array}$ & 36,77 \\
\hline 5 & $\begin{array}{l}\text { Mampu mempresentasikan hasil } \\
\text { diskusi dan eksperimen di depan } \\
\text { kelas }\end{array}$ & 12,51 \\
\hline Jumlah & 100 \\
\hline
\end{tabular}

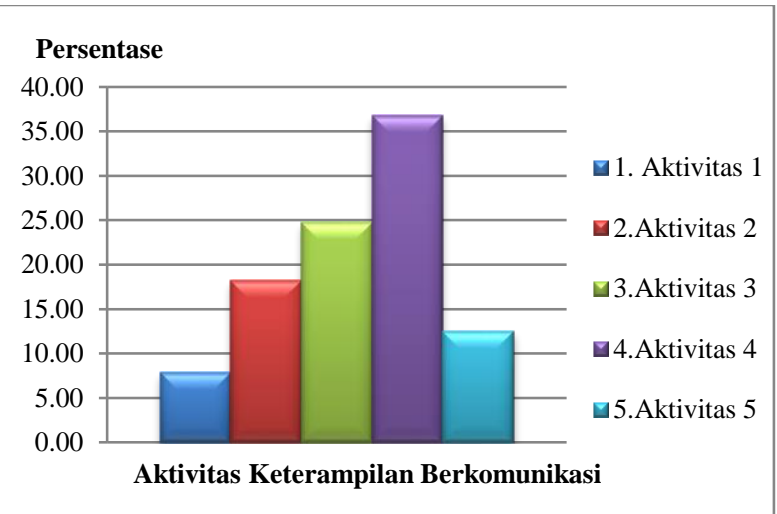

Gambar 3. Persentase Keterampilan Berkomunikasi Siswa

Berdasarkan diagram batang tentang persentaseketerampilan berkomunikasi siswa dapat diketahui bahwa keterampilan berkomunikasi siswa dari yang paling tinggi presentasenya adalah menanggapi pendapat siswa lain saat diskusi kelompok maupun diskusi kelas (36,77\%), menyumbang ide/ pendapat $(24,71 \%)$, menjawab pertanyaan (18,17\%), mempresentasikan hasil diskusi kelompok (12,51\%) dan yang terendah mengajukan pertanyaan $(7,85 \%)$. Pembelajaran kooperatif tipe NHT (Numbered Heads Together) terdapat fase berpikir bersama untuk menyatukan pendapat, peran ini digunakan saat diskusi antar kelompok, adanya peran ini siswa saling memotivasi untuk pemahaman materi, sehingga keterampilan berkomunikasi siswa dapat dikembangkan.

Sesuai dengan yang dituliskan Kennedy (2007), "Dabate as an active instructional strategy enhances learning particulary in the areas of mastering the content as well as developing critical thinking skills, oral communication skills, and empathy", yang berarti diskusi kelas atau presentasi sebagai strategi pembelajaran aktif dapat meningkatkan pembelajaran, khususnya penguasaan konten serta dapat meningkatkan keterampilan berpikir kritis, keterampilan berkomunikasi lisan, dan rasa empati.

3. Hasil Belajar Siswa

a. Sikap

Analisis ketuntasan hasil belajar sikap dapat dilihat pada Tabel 7.

Tabel 7. Ketuntasan Hasil Belajar Sikap

\begin{tabular}{|c|c|c|c|c|c|}
\hline \multirow[b]{2}{*}{ No } & \multirow{2}{*}{$\begin{array}{l}\text { Nama } \\
\text { Siswa }\end{array}$} & \multicolumn{2}{|c|}{ Rekapitulasi } & \multirow{2}{*}{$\begin{array}{l}\text { Predik } \\
\text { at }\end{array}$} & \multirow{2}{*}{$\begin{array}{c}\text { Ketuntas } \\
\text { an } \\
\text { Individu }\end{array}$} \\
\hline & & $\begin{array}{c}\text { Observa } \\
\text { si }\end{array}$ & $\begin{array}{l}\text { Penilaian } \\
\text { Diri }\end{array}$ & & \\
\hline 1 & $\mathrm{~A}$ & 3,56 & 3,50 & Baik & Tuntas \\
\hline 2 & $\mathrm{~B}$ & 3,33 & 3,17 & Baik & Tuntas \\
\hline 3 & $\mathrm{C}$ & 3,11 & 3,33 & Baik & Tuntas \\
\hline 4 & $\mathrm{D}$ & 3,11 & 3,17 & Baik & Tuntas \\
\hline 5 & $\mathrm{E}$ & 3,11 & 3,33 & Baik & Tuntas \\
\hline 6 & $\mathrm{~F}$ & 3,33 & 3,17 & Baik & Tuntas \\
\hline 7 & $\mathrm{G}$ & 3,11 & 3,17 & Baik & Tuntas \\
\hline 8 & $\mathrm{H}$ & 3,11 & 3,00 & Baik & Tuntas \\
\hline 9 & I & 3,11 & 3,33 & Baik & Tuntas \\
\hline 10 & $\mathrm{~J}$ & 3,11 & 3,17 & Baik & Tuntas \\
\hline 11 & $\mathrm{~K}$ & 3,11 & 3,50 & Baik & Tuntas \\
\hline 12 & $\mathrm{~L}$ & 3,56 & 3,50 & Baik & Tuntas \\
\hline 13 & $\mathrm{M}$ & 3,33 & 3,33 & Baik & Tuntas \\
\hline 14 & $\mathrm{~N}$ & 3,11 & 3,33 & Baik & Tuntas \\
\hline 15 & $\mathrm{O}$ & 3,33 & 3,00 & Baik & Tuntas \\
\hline 16 & $\mathrm{P}$ & 3,11 & 3,50 & Baik & Tuntas \\
\hline 17 & Q & 3,11 & 3,33 & Baik & Tuntas \\
\hline 18 & $\mathrm{R}$ & 3,33 & 3,33 & Baik & Tuntas \\
\hline 19 & $S$ & 3,33 & 3,33 & Baik & Tuntas \\
\hline 20 & $\mathrm{~T}$ & 3,33 & 3,33 & Baik & Tuntas \\
\hline 21 & $\mathrm{U}$ & 3,11 & 3,17 & Baik & Tuntas \\
\hline
\end{tabular}




\begin{tabular}{|l|c|c|c|c|c|}
\hline \hline 22 & $\mathrm{~V}$ & 3,33 & 3,50 & Baik & Tuntas \\
\hline 23 & $\mathrm{~W}$ & 3,33 & 3,50 & Baik & Tuntas \\
\hline 24 & $\mathrm{X}$ & 3,33 & 3,50 & Baik & Tuntas \\
\hline 25 & $\mathrm{Y}$ & 3,33 & 3,33 & Baik & Tuntas \\
\hline
\end{tabular}

Tabel 7 menunjukkan bahwa siswa memperoleh nilai sikap spiritual dan sosial terendah 3,00 dan tertinggi 3,56 dengan predikat baik. Ketuntasan belajar sikap yang ditetapkan sekolah yang diteliti berdasarkan Permendikbud nomor 59/2014 adalah siswa dikatakan tuntas secara individual apabila mendapat nilai sikap $\geq 3,00$ dengan kategori baik, artinya seluruh siswa mencapai ketuntasan pada aspek hasil belajar sikap.

\section{b. Pengetahuan}

Tes ini dilakukan untuk mengetahui penguasaan konsep siswa terhadap konsep-konsep yang diberikan selama pembelajaran. Pemberian pretest (diberikan kepada siswa sebelum memulai pembelajaran) dan posttest (diberikan setelah seluruh pembelajaran selesai dilaksanakan) bertujuan untul mengetahu sensitivitas setiap butir soal dan peningkatan nilai (gain-score) yang diperoleh setiap siswa.

Hasil pretest dan posttest pemahaman konsep dianalisis dengan analisis deskriptif kualitatif yaitu dengan menghitung rata-rata nilai pretest dan nilai posttest tersebut digunakan untuk menghitung skor gain ternormalisasi. Skor gain ternormalisasi tersebut digunakan untuk menentukan peningkatan pemahaman konsep siswa terhadap materi larutan elektrolit dan nonelektrolit antara sebelum dan sesudah pembelajaran.

Analisis ketuntasan hasil belajar pengetahuan dapat dilihat pada tabel 8 .

Tabel 8. Ketuntasan Hasil Belajar Pengetahuan

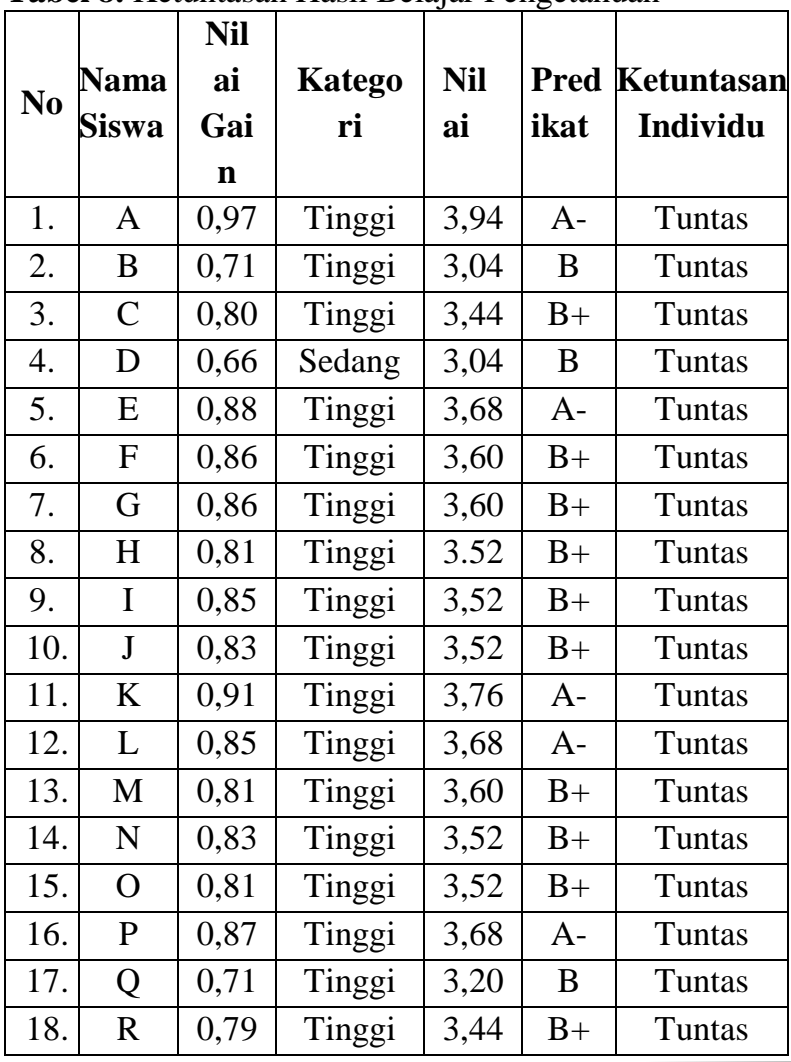

\begin{tabular}{|c|c|c|c|c|c|c|}
\hline 19. & S & 0,71 & Tinggi & 3,36 & B+ & Tuntas \\
\hline 20. & T & 0,88 & Tinggi & 3,68 & A- & Tuntas \\
\hline 21. & U & 0,79 & Tinggi & 3,44 & B + & Tuntas \\
\hline 22. & V & 0,73 & Tinggi & 3,20 & $\mathrm{~B}$ & Tuntas \\
\hline 23. & W & 0,79 & Tinggi & 3,52 & B+ & Tuntas \\
\hline 24. & X & 0,74 & Tinggi & 3,28 & B & Tuntas \\
\hline 25. & Y & 0,74 & Tinggi & 3,12 & B & Tuntas \\
\hline $\begin{array}{l}\text { Rata- } \\
\text { rata }\end{array}$ & $\mathbf{0 , 8 1}$ & Tinggi & $\mathbf{3 , 4 8}$ & B+ & Tuntas \\
\hline
\end{tabular}

Berdasarkan Tabel 8 diperoleh nilai peningkatan (gain score) yang dicapai setiap siswa berkisar antara 0,66 - 0,97 dengan rata-rata 0,81 . Hal ini sesuai dengan klasifkasi gain dari Hake (1998), maka peningkatan nilai (gain score) tes hasil belajar siswa tersebut tergolong tinggi.

\section{c. Keterampilan}

Analisis ketuntasan hasil belajar keterampilan dapat dilihat pada tabel 9.

Tabel 9. Ketuntasan hasil Belajar Keterampilan

\begin{tabular}{|c|c|c|c|c|}
\hline \multirow{2}{*}{ No } & \multirow{2}{*}{ Nama Siswa } & \multicolumn{2}{|c|}{$\begin{array}{c}\text { Hasil Belajar } \\
\text { Siswa }\end{array}$} & Ketuntasan \\
\cline { 3 - 5 } & & Nilai & Predikat & \\
\hline 1 & A & 4,00 & A & Tuntas \\
\hline 2 & B & 3,20 & B+ & Tuntas \\
\hline 3 & C & 3,47 & B+ & Tuntas \\
\hline 4 & D & 3,73 & A- & Tuntas \\
\hline 5 & E & 3,73 & A- & Tuntas \\
\hline 6 & F & 3,20 & B & Tuntas \\
\hline 7 & G & 3,47 & B+ & Tuntas \\
\hline 8 & H & 3,20 & B & Tuntas \\
\hline 9 & I & 3,20 & B & Tuntas \\
\hline 10 & J & 3,47 & B+ & Tuntas \\
\hline 11 & K & 3,73 & A- & Tuntas \\
\hline 12 & L & 4,00 & A & Tuntas \\
\hline 13 & M & 3,20 & B & Tuntas \\
\hline 14 & N & 3,20 & B & Tuntas \\
\hline 15 & O & 3,47 & B+ & Tuntas \\
\hline 16 & P & 3,73 & A- & Tuntas \\
\hline 17 & Q & 3,20 & B & Tuntas \\
\hline 18 & R & 3,73 & A- & Tuntas \\
\hline 19 & S & 3,20 & B & Tuntas \\
\hline 20 & T & 3,73 & A- & Tuntas \\
\hline 21 & U & 3,47 & B+ & Tuntas \\
\hline 22 & V & 3,20 & B+ & Tuntas \\
\hline 23 & W & 3,47 & B+ & Tuntas \\
\hline 24 & X & 3,20 & B+ & Tuntas \\
\hline 25 & Y & 3,20 & B+ & Tuntas \\
\hline & Rata-rata & $\mathbf{3 , 4 6}$ & B+ & Tuntas \\
\hline
\end{tabular}

Tabel 9 menunjukkan bahwa hasil belajar aspek keterampilan pada pembelajaran terhadap 25 orang siswa dengan nilai terendah 3,20 predikat $\mathrm{B}$ dan 
tertinggi 4,00 predikat A. Ketuntasan belajar keterampilan yang ditentukan sekolah yang diteliti berdasarkan Permendikbud nomor 59/2014 adalah siswa dikatakan tuntas secara individual apabila mendapat nilai keterampilan $\geq 3,00$ dengan predikat $\mathrm{B}$.

\section{KESIMPULAN}

\section{A. Simpulan}

Berdasarkan analisis, pembahasan, dan temuan hasil penelitian dapat disimpulkan bahwa perangkat pembelajaran kooperatif tipe NHT (Numbered Heads Together) layak (valid, praktis, dan efektif) digunakan untuk melatihkan keterampilan berkomunikasi dan meningkatkan hasil belajar pada materi larutan elektrolit dan nonelektrolit.

\section{B. Saran}

Beberapa saran dari hasil penelitian yang dilakukan adalah sebagai berikut:

1. Diperlukan persiapan dan pengelolaan waktu secara cermat, karena penerapan kegiatan belajar mengajar (KBM) ini memerlukan waktu yang relatif lama.

2. Penelitian ini perlu dikembangkan lebih lanjut untuk pokok bahasan lain guna melatihkan keterampilan berkomunikasi siswa.

\section{REFERENSI}

Arikunto, Suharsini. (2010). Prosedur Penelitian: Suatu Pendekatan Praktik. Jakarta: Rineka Cipta.

Citrobroto,S.(1982).Prinsip-Prinsip dan Teknik Berkomunikasi. Jakarta: Bhratara Karya Aksara.

Hake, Richard R. (1998). Analyzing Change/Gain Score Dept. of Physics, India University 24245 Hateras Street, Woodland Hills, CA, 91367 US.A

Huda, Miftahul. (2011). Cooperatif Learning. Yokyakarta: Pustaka Pelajar.

Kemendikbud, (2013).Permendikbud nomor 65 tahun 2013 tentang Standar Proses Pendidikan Dasar dan Menengah, Jakarta : Kemendikbud.

Kemendikbud, (2013).Permendikbud RI Nomor 81A tahun 2013, Tentang Implementasi Kurikulum,Jakarta : Kemendikbud.

Kemendikbud, (2014).Permendikbud RI Nomor 59 tahun 2014, TentangKurikulum 2013 Sekolah Menengah Atas/Madrasah Aliyah, Jakarta : Kemendikbud.

Mulyasa, H. E. (2013). Pengembangan dan Implementasi Kurikulum 2013. Bandung: PT. Remaja Rosdakarya.

Ibrahim, Muslimin. (2002). Pengembangan Perangkat Pembelajaran (Modul Terintegrasi Berbasis Kompetensi Guru Mata Pelajaran Biologi SLTP). Jakarta Depdiknas.

Isjoni. (2009). Pembelajaran Kooperatif: Meningkatkan Kecerdasan Komunikasi antar Peserta Didik. Yokyakarta: Pustaka Pelajar.

Kennedy, Ruth. (2007). "In Class Debates: Fertile Ground for Active Learning and the Cultivation of Critical Thinking and Oral Communication Skills". International Journal of Teaching and Learning in Higher Education. Vol.19, No.2, pp.183-190

Rabbani, Abdan, Syakur, Waslaluddin, MT., Rahman, Eka, dan Fitrajaya. (2013). "Implementasi Model Pembelajaran Kooperatif Tipe NHT untuk Meningkatkan Kemampuan Pemahaman Siswa ada Mata Pelajaran TIK". Journal Universitas Pendidikan Indonesia. Vol. 1 No.1.

Rositawati, Tita. (2012). "Model Pembelajaran Kooperatif Tipe NHT (Numbered Heads Together) untuk Meningkatkan Aktivitas Kerja Kelompok dan Hasil Belajar Siswa". Jurnal Universitas Pendidikan Indonesia. Vol. III No.1.

Wagner, T. (2008). The Global Achievement Gap. New York: Basic Books

Zakaria, E,. Chin, L, C,. And Daud, M. (2010). "The Effects of Cooperative Learning on Students' Mathematics Achievement and Attitude towards Mathematics". Journal of Social Science. Vol. 6 No.2, pp. 272-275.

Zuhra, F. (2013). Pengembangan Perangkat Pembelajaran Kooperatif Tipe Jigsaw II untuk Melatihkan Keterampilan Berkomunikasi pada Pokok Bahasan Bunyi (Tesis magister pendidikan tidak dipublikasikan). Universitas Negeri Surabaya. 